\title{
Investigation on railway investment-induced neighborhood change and local spatial spillover effects in Nagoya, Japan
}

\author{
Lisha Wang (corresponding author) \\ Nagoya University \\ wang.lisha@e.mbox.nagoya-u.ac.jp \\ Meilan Jiang \\ Nagoya University \\ jiangml@trans.civil.nagoya-u.ac.jp
}

\author{
Tomio Miwa \\ Nagoya University \\ miwa@nagoya-u.jp \\ Takayuki Morikawa \\ Nagoya University \\ morikawa@nagoya-u.jp
}

\begin{abstract}
Previous studies have proven the significant causal relationship between railway investment and gentrification in some cities. However, most of them have focused on the gentry and less on the effect on other social classes. To observe how railway investment affects neighborhood change for different population types, this study investigated the investment effects of two urban railway lines separately on the neighborhood change of the gentry, older population, and students in Nagoya, Japan. These two railway lines consisting of a subway and an elevated railway opened in the same year and were located in different areas of the city. Moreover, the spatial autocorrelation in panel data was considered to investigate possible local spillover effects. Finally, we observed that the railway investments in highly urbanized areas were more likely to induce gentrification. In addition, railway investment has some significant treatment effects on students compared to the older population.
\end{abstract}

\section{Article history:}

Received: March 24, 2020

Received in revised form: March 4, 2021

Accepted: April 2, 2021

Available online: June 24, 2021

\section{Introduction}

Newman and Kenworthy (1999) state that the railway investment in urban areas can utilize market forces to construct abundant commercial and entertainment facilities around railway stations, which will attract more residents to live along railway lines. The question is which social classes of the population would be more attached to the residences near railway stations. Researchers have proven that the railway investments and expansion brought gentrification to some cities ( Bardaka, Delgado, \& Florax, 2018; Kahn, 2007). Gentrification is the neighborhood change process of the gentry, who are young, educated, unmarried, and/or childless professionals (Grossmann \& Haase, 2016; Helms, 2003). However, few studies investigate the effects on other social classes. From Ministry of Land, Infrastructure, Transport and Tourism (MLIT), the share of railway transport is higher for older population in the three metropolitan areas than other regions in Japan. Therefore, in this study, we investigated the railway-induced effect on the neighborhood change of older population as well as the gentry to provide references for transportation policy making in Nagoya city. Meanwhile, Nagoya Personal Trip Survey indicates that railway is the main mode for students to go to school. For comparison, the effects on stu-

Copyright 2021 Lisha Wang, Tomio Miwa, Meilan Jiang \& Takayuki Morikawa

http://dx.doi.org/10.5198/jtlu.2021.1763

ISSN: $1938-7849$ | Licensed under the Creative Commons Attribution - Noncommercial License 4.0

The Journal of Transport and Land Use is the official journal of the World Society for Transport and Land Use (WSTLUR) and is published and sponsored by the University of Minnesota Center for Transportation Studies. 
dents are also investigated. From the health perspective, Japan has encouraged cycling since 1961, and even enacted legislation to build four types of bicycle lanes. As a result, the multimode bicycle-railway daily trips are very common in Japan. Hence, in this paper, authors also investigate whether the railway investments have spillover effects on the neighborhoods which are not close to railway stations but can be easily covered using a bike.

In this paper, neighborhood change induced by two regional railway transit lines (Meijo line and Aonami line) in Nagoya city are investigated. Both lines opened in October 2004, but they are located in different areas in the city and undertake different transportation tasks. First, the theoretical background of existing methodologies and the modelling approach are discussed in a comprehensible way, then authors explain the data source. Based on the geographic influence scale in the preliminary study, the standard DID panel data model is implemented to investigate neighborhood change for each lines. Thereafter, authors perform the Lagrange multiplier (LM) test and incorporate spatial DID model with spatial error components to capture the spatial autocorrelation in panel data. Then the model estimation results and findings are presented. Finally, authors discuss prospects for future work.

\section{$2 \quad$ Literature review}

\subsection{1 Neighborhood change}

There is substantial evidence that transit-oriented development (TOD) contributes to urban development in some large cities with high population density. TOD not only provides convenient railway transportation services but also includes some commercial investments. The area along railway line can gradually develop into a good residential area and attract residents to live around railway stations. Consequently, land prices rise along the railway lines, which attracts more reinvestments in return. This is a positive city development cycle. TransLink describes TOD as "concentrating higher-density, mixed-use, human-scale development around frequent transit stops and stations, in combination with mobility management measures to discourage unnecessary driving." Lin (2002) found that property values close to transit stations were $20 \%$ more than those half a mile away in northwest Chicago. Bluestone, Huff Stevenson, and Williams (2008) reported that scholars observed the occurrence of thriving commercial activities usually in the area around transit stops where the introduced business facilities are appealing for both commuters and non-commuters. The accessibility of transit and transit-oriented districts makes them desirable amenities in urban neighborhoods (Zuk, Bierbaum, Chapple, Gorska, \& LoukaitouSideris, 2018).

Most previous studies connect TOD and the neighborhood change of the gentry, called "gentrification." Gentrification was coined by Ruth Glass to describe the process that working-class occupiers were displaced by middle-class in London in 1964. Helms (2003) noted that "gentrification contains two processes: upper-income resettlement and housing renovation," which are treated as independent phenomena and modeled separately in his studies. Slater (2011) stated that the profitable redevelopment in urban area to satisfy the requirements of business and policy elites commonly induces gentrification. Zuk et al. (2018) claimed that TOD can increase the appeal of urban areas and may cause residential gentrification or accelerate the existing gentrification. Bardaka et al. (2018) observed the strong effects of the first light railway investment on urban gentrification. Nevertheless, people living "too close" to railway stations may have to bear some uncomfortable effects, such as noise, traffic congestion, and poor environment (Cervero, 2010; Kahn, 2007; Kilpatrick, Throupe, Carruthers, \& Krause, 2007). It confirms that transit access has both positive and negative effects on gentrification. However, few research studies have studied this in Japan. Therefore, this study aims to investigate the railway-induced effects 
on the residential gentrification in Nagoya city.

Based on the Statistics Bureau of Japan, the older population (the population aged 65 years and above) was 35.58 million in 2018 , accounting for $28.1 \%$ of the total population. Meanwhile, the National Institute of Population and Social Security Research predicts that the percentage of the older population will rise to $30.0 \%$ in 2025 and $35.3 \%$ in 2040 in Japan. For the older, car is the principal mode of transport besides walking. However, the number of traffic accidents caused by driving errors of the older kept increasing during the period of 2010-2019. It has become a serious social problem in Japan. The government is trying to find appropriate ways to solve this issue. Since the share of railway infrastructure is higher in the three metropolitan areas than other regions in Japan, one common strategy is to encourage the older to use public transport more frequently. Therefore, in this study, we measured the railway-induced effect on older population by testing whether the residences along the railway stations can encourage them to change their residence area. Some studies have explored the residential location choice of the older. Florida (2010) shows the low migration preference and longer migration distance of American elders. Barsby and Cox (1975) and Plane and Jurjevich (2009) explored the characteristics of the preferred destination of migrant elders. Subsequently, Park and Kim (2016) explored 4009 older householders in South Korea and established a residential movement model for them. However, few studies have explored the effects of railway investment on the older. Meanwhile, since railway is the main transportation mode for students, to observe the railway investment induced residential preferences at different social classes, the effects on students are investigated as well.

\subsection{Methodological concerns}

Many researchers have performed studies in measuring railway investment-induced neighborhood change. Hammel and Wyly (1996) selected variables to measure gentrification by the stepwise method and canonical discriminant analysis and obtained high regression accuracy. Atkinson (2000) overcame the drawbacks of aggregated data by establishing new approaches that combined cross-sectional data with spatially aggregated longitudinal census data to measure gentrification. Taking 102 tracts in San Francisco Bay Area from 1999 to 2000, for instance, Chapple et al. (2009) utilized multivariate regression to identify different categories of factors that may encourage the neighborhood to gentrify. These factors include demographic, income, transportation, housing, and locational factors including amenities. Finally, Chapple et al. (2009) found that only $7 \%$ neighborhoods gentrify and the neighborhoods with high score on local amenities, transit commuting and income diversity probably gentrify at some point in the near future. Grube-Cavers and Patterson (2015) argued that utilizing event analysis approach is more effective in measuring gentrification. Using the proposed methodological framework, they found that "proximity to railway and other gentrifying census tracts have a statistically significant effect on gentrification in two of the three cities analyzed in Canada." Considering the change in environment over time and the spatial spillover effect, Bardaka et al. (2018) utilized DID and spatial DID models to measure railway-induced gentrification. Chi and Voss (2005) proved that the hierarchical regression approach is more significant than multivariate regression in migration decision-making. Hence, a multilevel logit model was applied to observe the residential location choice behavior of the older (Park $\&$ Kim, 2016). These methods can be utilized to investigate the relationship among railway investment, older population, and students.

To measure the effect on neighborhood change, the usual approach is to calculate the difference before and after railway construction. However, other socioeconomic factors may also have influences during that period. Inspired by Delgado and Florax (2015), in the present study, we utilized DID panel data model with spatial autocorrelation to investigate neighborhood change process. DID model has a quasi-experimental design, which contains a treated group and control group. In its setup, the control 
group is used to eliminate the impact of other factors, thus the difference between the treated group and the control group is the average treatment effect of railway investment. Moreover, the DID model assumes that there are no interactions among individuals (stable unit treatment value assumption). However, the spatial autocorrelation may exist in panel data, in which case the estimation result of the DID model is biased and inconsistent (Bardaka et al., 2018). Hence, researchers proposed spatial DID model to capture spatial interactions across spatial units. Dubé, Legros, Thériault, and Des Rosiers (2014) combines the DID model with spatial autoregressive in dependent variable to account for global spillover effect. Delgado and Florax (2015) proposed another different spatial DID model to measure local spatial spillover effects. In this research, we focus on local spillover effects.

First, the baseline DID model is utilized to observe railway-induced effects on the neighborhoods near railway stations. Then, the spatial autocorrelation in panel data is tested, and the robustness of spatial components and random effects in models is discussed via LM tests. The local spillover effect of two railway lines are also investigated. Finally, the estimated results in two lines are compared.

\section{$3 \quad$ Methods}

\subsection{DID panel data model}

DID model has a quasi-experimental design. In its setup, all the neighborhoods are divided into treated group and control group. In this study, the neighborhoods within a certain geographical scale of a railway station are placed in the treated group, whereas others that are in the study area are classified in the control group. Here, we defined the railway investment as "treatment."

The dataset contained time series and cross-section dimensions, which is also known as panel data. Based on the poolability assumption, the same coefficients were applied across all individuals. Thus, the dataset is the pooling of observations on a cross-section of neighborhoods $i(i=1, \ldots, N)$ over two time periods (before and after treatment). However, the effectiveness of the DID model depends on some assumptions. Among them, the parallel trend assumption is the prominent, which requires that the average outcomes for the treated and control groups should follow the parallel trends over time (Abadie, 2005). Additionally, the stable unit of treatment value assumption (SUTVA) requires all the neighborhoods to not interfere with others, and all the parameters were assumed to be linear in regression. Then, the DID panel data model is specified as:

$\mathrm{y}=\alpha_{1} l+\alpha_{2} G+\alpha_{3} T+\alpha_{4} G \circ T+\beta X+\mu$

where $l$ is a column of ones and $G$ is a group dummy $\left(G_{i}=1\left(G_{i} \in\{0,1\}\right)\right.$ indicates that neighborhood $i$ is in the treated group); $T$ is time dummy $\left(T_{i}=1\left(T_{i} \in\{0,1\}\right)\right.$ indicates the time period after treatment); $G \circ T$ presents the policy dummy, that is, the Hadamard product of $G$ and $T ; X$ is the vector of explanatory variables; $\beta$ is the vector of regression coefficients; and $\mu$ is a mean-zero error term. To guarantee the consistency of estimation, $\mu$ should be uncorrelated with $G$ and $T$.

In panel data, with or without unobservable time-specific effect in error term $(\mu)$, panel data model is classified into one-way and two-way error component models. Specifically, when the cross-sectional dimension $\mathrm{N}$ vastly exceeds the time dimension $\mathrm{T}$, it is better to choose one-way error component model to simplify the calculation. Therefore, in this study, we utilized the one-way error component. It is defined as: 
$\mu_{i t}=u_{i}+v_{i t}$

where $\mu_{i t}$ is the disturbance term for neighborhood $i$ at time $t$; $u_{i}$ is the unobservable individualspecific effect, that is, invariant with time; and $v_{i t}$ is the remainder disturbance, which can be treated as the usual disturbance. We assumed that the effects are random in the model, thus $u_{i} \sim \operatorname{IID}\left(0, \sigma_{u}^{2}\right)$.

As shown in Figure 1, the railway-induced average treatment effect is the difference between the differences of outcomes in two groups. Based on Equation 1 and the above assumptions, the average treatment effect (ATE) is given as:

$$
\begin{aligned}
\mathrm{ATE} & =\left(\overline{\mathrm{y}}_{\text {treatafter }}-\overline{\mathrm{y}}_{\text {treat,before }}\right)-\left(\overline{\mathrm{y}}_{\text {control,after }}-\overline{\mathrm{y}}_{\text {control,before }}\right) \\
& =[\mathrm{E}(\mathrm{y} \mid \mathrm{G}=1, \mathrm{~T}=1)-\mathrm{E}(\mathrm{y} \mid \mathrm{G}=1, \mathrm{~T}=0)]-[\mathrm{E}(\mathrm{y} \mid \mathrm{G}=0, \mathrm{~T}=1)-\mathrm{E}(\mathrm{y} \mid \mathrm{G}=0, \mathrm{~T}=0)] \\
& =\left[\alpha_{3}+\alpha_{4}\right]-\left[\alpha_{3}\right] \\
& =\alpha_{4}
\end{aligned}
$$

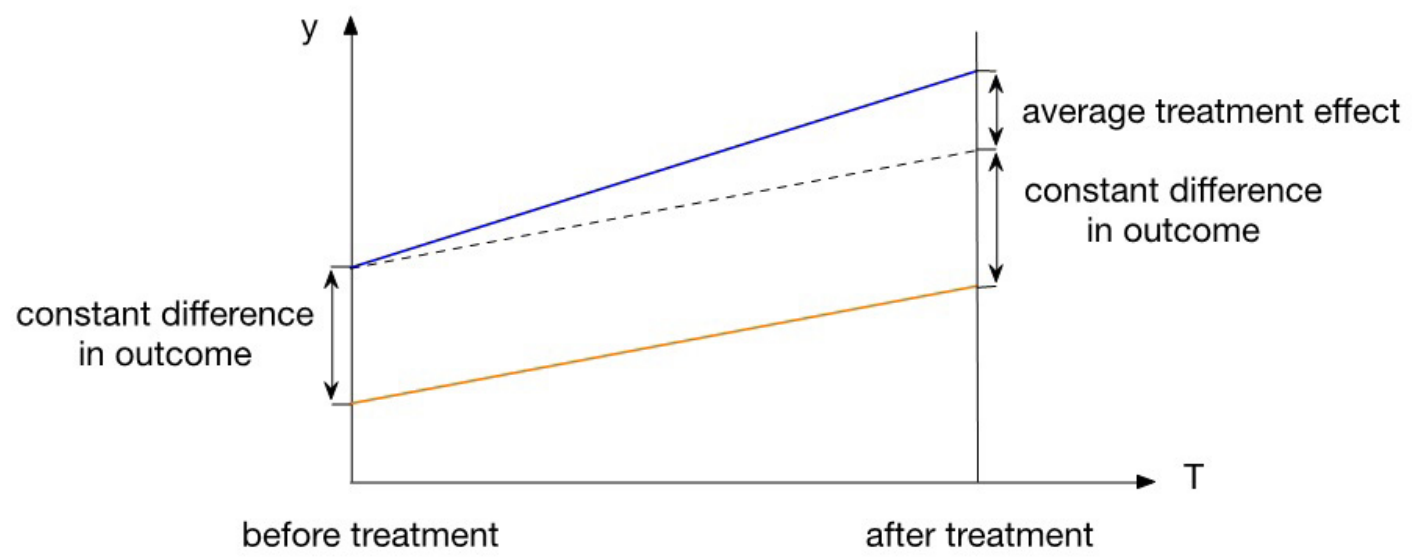

observed outcome trend in treated group

observed outcome trend in control group

Figure 1. Graphical illustration of DID model

\subsection{Spatial DID model}

Once there are social interaction or interference among neighborhoods, the SUTA assumption will be broken. In this case, the DID model is inconsistent and biased. Therefore, Delgado and Florax (2015) proposed a spatial DID model to consider the spatial correlation in treatments and spatial interaction in treatment responses. Different from global case, this spatial DID model focus on local spatial spillover. Local spatial spillover means that the spatial effects are only restricted to close neighbors that are defined on contiguity or distance. In spatial DID model setup, all individuals are classified into three groups: directly treated group, indirectly treated group, and control group. The effect on directly treated group is defined as directly treated effect, and the effect on indirectly treated group is defined as indirectly treated effect, or local spillover effect. The equation of the spatial DID model is written as:

$$
\begin{aligned}
y & =\alpha_{1} l+\alpha_{2} G+\alpha_{3} T+\alpha_{4}(I+\lambda W) G \circ T+\beta X+\mu \\
& =\alpha_{1} l+\alpha_{2} G+\alpha_{3} T+\alpha_{4} G^{\circ} T+\lambda \alpha_{4} W G^{\circ} T+\beta X+\mu \\
& =\alpha_{1} l+\alpha_{2} G+\alpha_{3} T+\alpha_{4} G^{\circ} T+\alpha_{4, \lambda} W G^{\circ} T+\beta X+\mu
\end{aligned}
$$


where $\lambda$ is the spatial autoregressive parameter; $W$ represents the local spatial interaction in treatment responses. $W=I_{T} \otimes W_{N}$, in which $I_{T}$ is the identity matrix of dimension $T$ (time) and $W_{N}$ is the spatial weight matrix $\left(N \times N\right.$ positive matrix with zero diagonal). Thus, $W=b \operatorname{diag}\left(W_{N}\right)$ is a $(T N \times T N)$ block diagonal of $W_{N}$ overtime. If the spatial autoregressive parameter $(\lambda)$ is equal to zero, Equation 4 is DID model; if $\lambda \neq 0$, the average treatment effect can be calculated as:

$$
\begin{aligned}
\operatorname{ATE}(w d)= & \left(\bar{y}_{\text {treat,after }}-\bar{y}_{\text {treat,before }}\right)-\left(\bar{y}_{\text {control,after }}-\bar{y}_{\text {control,before }}\right) \\
= & \{\mathrm{E}[\mathrm{y} \mid \mathrm{X}, \mathrm{G}=1, \mathrm{~T}=1, \mathrm{WG}=\mathrm{wg}]-\mathrm{E}[\mathrm{y} \mid \mathrm{X}, \mathrm{G}=1, \mathrm{~T}=0, \mathrm{WG}=\mathrm{wg}]\} \\
& -\{\mathrm{E}[\mathrm{y} \mid \mathrm{X}, \mathrm{G}=0, \mathrm{~T}=1, \mathrm{WG}=0]-\mathrm{E}[\mathrm{y} \mid \mathrm{X}, \mathrm{G}=0, \mathrm{~T}=0, \mathrm{WG}=0]\} \\
= & \alpha_{4}+\alpha_{4, \lambda} w g
\end{aligned}
$$

The total average treatment effect is:

$$
\mathrm{ATE}=\mathrm{E}[\mathrm{ATE}(w g) \mid W G]=\alpha_{4}+\alpha_{4, \lambda} \overline{W G}
$$

where $w g \in W G, w g \in[0,1] . \overline{W G}$ is the average proportion of treated neighborhoods. ATE can be decomposed into average directly treatment effect $\left(\mathrm{ADTE}=\alpha_{4}\right)$ and average indirectly treatment effect $\left(\mathrm{AITE}=\alpha_{4, \lambda}(\overline{W G})\right.$.

\subsection{Spatial error component}

Considering the correlation of economic characteristics in space, the spatial dependence effect may exist in the disturbance error term. Hence, we incorporate model with spatial error component. There are two specifications for the disturbance $\mu$. One was established by Baltagi, Song, \& Koh (2003) and the other was established by Kapoor et al. (2007). As it is more difficult to calculate the specification proposed by Baltagi et al. (2003), we utilized the one established by Kapoor, Kelejian, and Prucha (2007) in this study. In the Kapoor et al. (2007) one-way random effects error component model, disturbance $\mu$ is expressed as follows:

$\mu=\rho\left(I_{T} \otimes W N\right) \mu+\epsilon$

$\epsilon=\left(l_{T} \otimes I_{N}\right) u+v$

where $\rho$ is the spatial autoregressive parameter, and $\epsilon$ is the spatially uncorrelated disturbances; $l_{T}$ is a column of ones, $I_{N}$ is an identity matrix of size $N$; $u$ is the unobservable individual-specific effect with zero-mean and finite variance $\sigma_{u}^{2}$; and $v$ is the remainder disturbance with zero-mean and finite variance $\sigma_{v}^{2}$

\subsection{Data description}

\subsubsection{Data source and study area}

In this study, Meijo line and Aonami line in Nagoya were observed (Fig. 2). As the capital of Aichi prefecture, Nagoya is the center of third-largest metropolitan region in Japan. Nagoya subway network 
includes six railway lines and 87 stations and covers $93.3 \mathrm{~km}$ as of 2019. As a loop line in this network, the first section of Meijo line operated in 1965 and the eastern section opened in October 2004. In this study, due to the lack of data for earlier years, we only studied the eastern part of Meijo line (hereafter Meijo line). Meijo line operates around city center and connects all other subway lines, and the urbanization along Meijo line is very high. Hence, the residents along Meijo line can enjoy convenient commercial and transportation facilities. Aonami line was derived from freight railway and has served both passengers and freight since 2004 . However, as this is the only railway line, the accessibility of area around Aonami line is poor and there is no mature business district along this line.

Usually, residents walk or cycle to railway stations in Japan. As shown in Figure 2, all the stations on Meijo line and most stations on Aonami line have bicycle parking lots. There are no car parking lots near Meijo line stations except for a small one near Jiyūgaoka station and an underground one in Ōzone station, which connects different railway lines. Three stations on Aonami line have nearby car parking lots. The information about bicycle parking lots also indicate that the multimode bicycle-railway daily trips are popular and convenient in Nagoya.

Since both lines operated in the same year (2004), we defined the year 2000 as the time before treatment and the year 2010 as the time after treatment. Based on census survey data in 2000 and 2010, "cho" was defined as the analysis unit. In census survey, some sparsely populated census tracts were hidden in nearby tracts due to privacy protection. Meanwhile, some land is only designed for commerce, industry, public green space and so on. For instance, the area around Kinjō-futō station and Noseki station is occupied by many commercial, sightseeing, and industrial facilities (Legoland Japan, SCMaglev and Railway Park and logistics center, etc.), and there is no residential land. Thus, we matched the "cho" in the two years and removed all hidden census tracts and unpopulated area. Finally, the number of residential neighborhoods was fixed at 1358 for both years (study area in Figure 2).

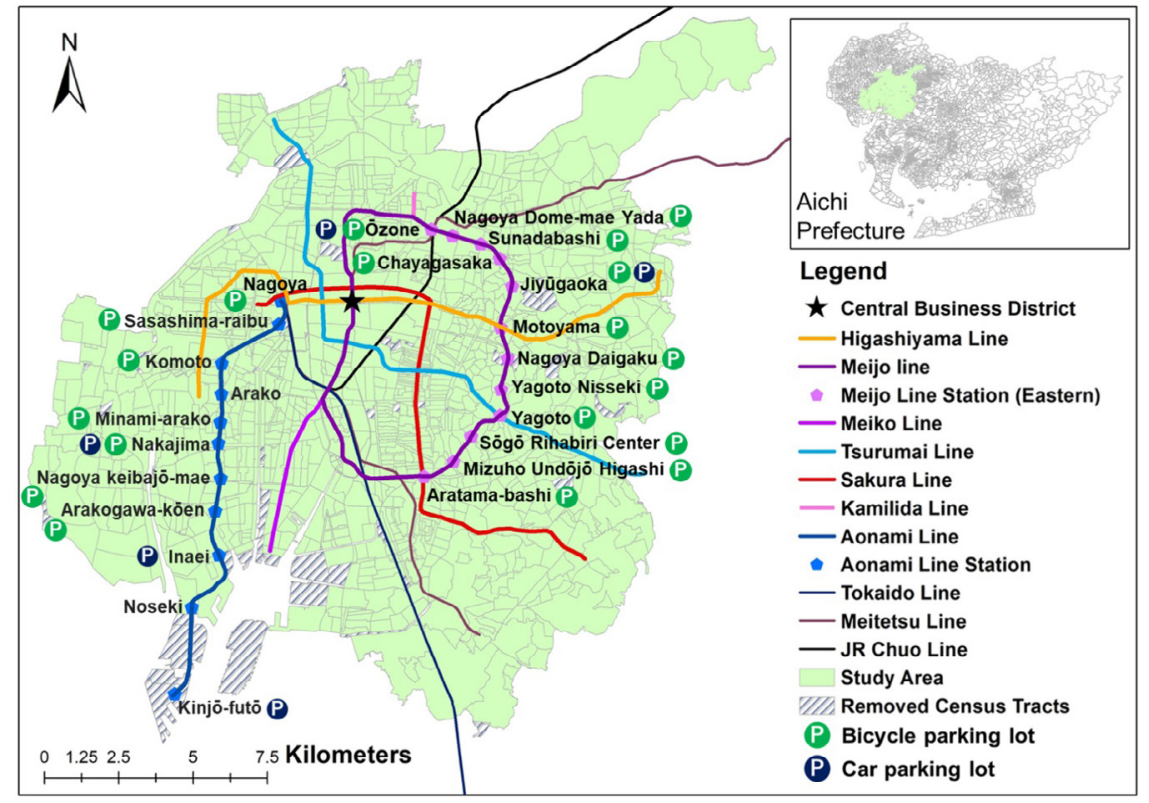

Figure 2. Data source and study area 


\subsubsection{Group classification}

In DID model setup, neighborhoods within a certain distance of a railway station are in the treated group, and the others within the study area are in control group. To understand the differences among various influence scales for treated and control groups, Wang. Jiang, Miwa, Bardaka, and Morikawa (2020) examined six different geographical scales for each line and finally determined the one that provides the best goodness-of-fit of the model: the scale of the study area is $5 \mathrm{~km}$ for both lines, and the suitable treated geographical scale for Meijo line is $0.8 \mathrm{~km}$ while it is $1 \mathrm{~km}$ for Aonami line.

In this study, when considering local spatial spillover in panel data, all the neighborhoods are classified into three groups: directly treated group, indirectly treated group, and control group. In this setup, the neighborhoods within $0.8 \mathrm{~km}(1 \mathrm{~km})$ in Meijo line (Aonami line) belong to the directly treated group. The indirectly treated group aims to reflect the spatial interaction among individuals, therefore, the neighborhoods within $0.8 \mathrm{~km}(1 \mathrm{~km})$ of (at least) one directly treated neighborhood in Meijo line (Aonami line) are in the indirectly treated group. The remaining neighborhoods within the study scale $(5 \mathrm{~km})$ in Meijo line (Aonami line) are in the control group. Figures 3 and 4 show the study area for each line separately.

Notably, Aonami line starts from Nagoya station that is a hub station with introduce of conventional Japan Railways lines, Shinkansen, Aonami line and Nagoya subway lines. Meanwhile, this station is adjacent to central business district (CBD). To eliminate the influence caused by other complicated factors, we removed the neighborhoods around Nagoya station and Sasahima-raibu station from study area as shown in Figure 4.

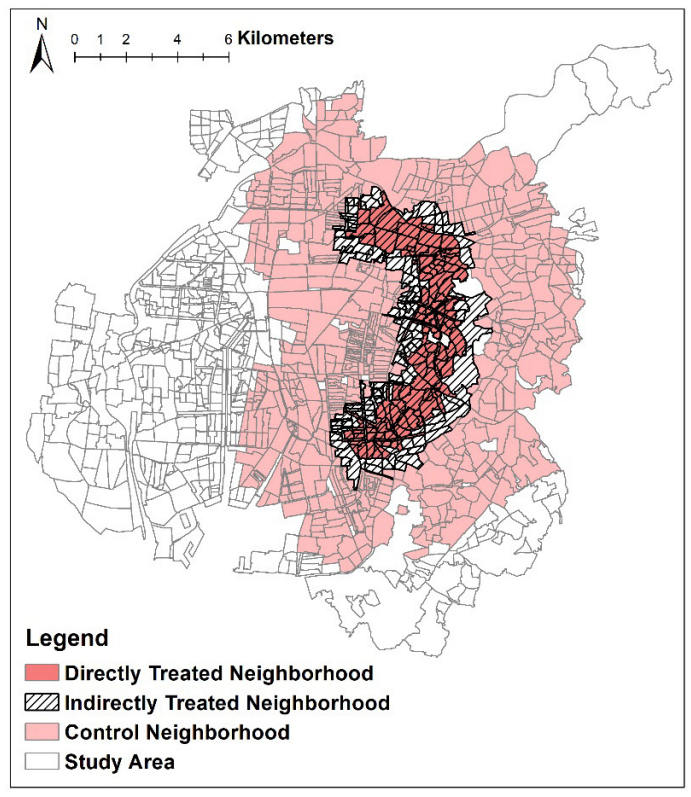

Figure 3. Meijo line study area

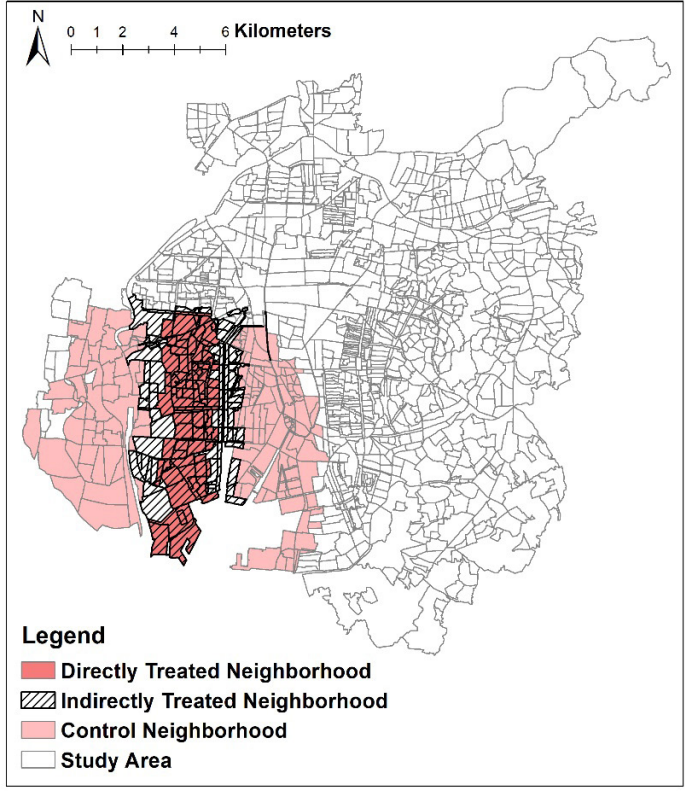

Figure 4. Aonami line study area 


\subsubsection{Variables' definitions and descriptive statistics}

In this paper, the average household income, educational attainment, managerial occupation, and professional occupation were used to measure the gentry. Additionally, the percentage of older population and students were used to measure migration of seniors and young people. All the dependent and explanatory variables are defined in Table 1.

Table 1. Description of variables

\begin{tabular}{|ll|}
\hline Dependent Variables & Definition \\
\hline Household income & Average household income of census tract (10,000 Yen/household in 2018 Yen) \\
Educational attainment & Percentage of population above 25 years old with a bachelor's degree or higher \\
Managerial occupation & Percentage of employed population in management positions \\
Professional occupation & Percentage of employed population in professional and technical occupations \\
Older percentage & Percentage of older population (65 years old or older) \\
Student percentage & Percentage of students \\
\hline Explanatory Variables & Definition \\
\hline Population density & Population divided by census tract's area (people per square kilometer) \\
Average age & Average age of the population in each census tract \\
Percent foreigners & Percentage of foreigners out of total population \\
Percent owner-occupied & Percentage of owner-occupied units out of total occupied units \\
Percent labor force & Percentage of population above 15 years old and in the labor force \\
Distance to CBD & Distance between the centroid of census tract and the CBD in kilometers \\
Migration rate & Percentage of residents that moved in between 2005 and 2010 \\
Worker percent railway & Percentage of employed population above 15 years old commuting by railway transportation \\
Student percent railway & Percentage of student population commuting by railway transportation \\
\hline
\end{tabular}

\subsubsection{Economic situation analysis}

Based on data from the Statistics Bureau of Japan, the average household annual income decreased by 12.8\% between 2000 and 2010 in Japan. After adjusting for inflation between the two years in 2018, Fig. 5 and Table 2 present the average household income level of all neighborhoods in Nagoya in two different years. The lowest average household income was 3.70 million Yen, and there were some neighborhoods whose average household income was more than 7.0 million Yen in 2000. In 2010, the lowest average household income was 2.96 million Yen, and there was only one neighborhood that had more than 7.0 million Yen. Moreover, no neighborhood's household income was higher than 10 million Yen in both years. 


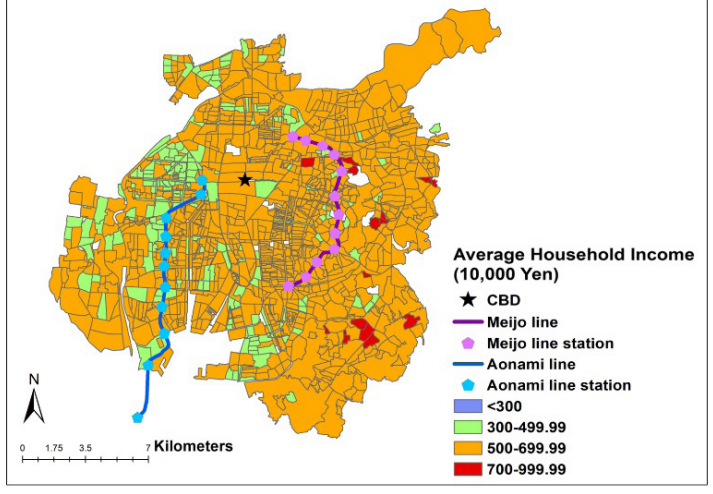

(a)Household income in 2000

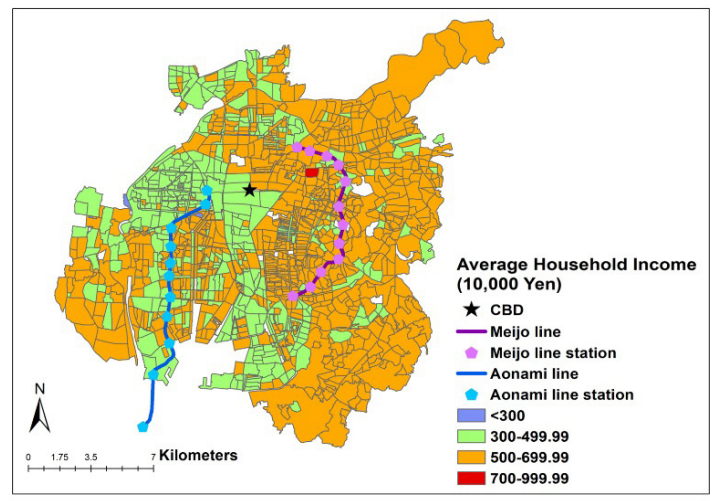

(b) Household income in 2010

Figure 5. Household income in Nagoya

Table 2. Summary of household income (10,000 Yen/household) in Nagoya city

\begin{tabular}{|l|l|l|l|l|l|}
\hline & Mean & St.dev & Median & Min & Max \\
\hline 2000 & 558.79 & 62.34 & 555.85 & 369.73 & 739.04 \\
\hline 2010 & 521.06 & 62.95 & 525.00 & 296.38 & 711.31 \\
\hline
\end{tabular}

\section{$4 \quad$ Estimation}

\subsection{Parallel trends assumption test}

The traditional method for testing the parallel trends assumption is to compare the observed average outcome trend in treated group and control group before treatment. Therefore, six measures (average household income, educational attainment, managerial occupation, and professional occupation, older percentage and student percentage) in 1995 and 2000 are investigated. However, owing to the lack of data in year 1995, we could only observe the trends of three measures (managerial occupation, professional occupation and older percentage), which is shown in Figures 6 and 7. In Meijo line, we observed a constant trend between 1995 and 2000, but this trend was less apparent for the older percentage. In Aonami line, the parallel trend is more obvious in terms of professional occupation and the older percentage than managerial occupation. However, these time paths are unconditional, hence we apply exogenous variables into regression to adjust any slight differences between two groups. 


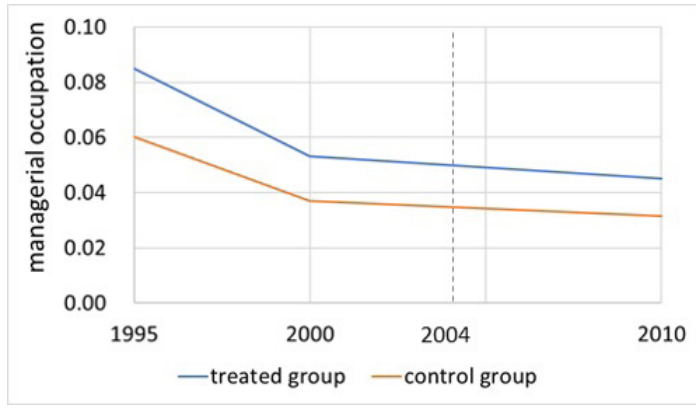

a) Managerial occupation

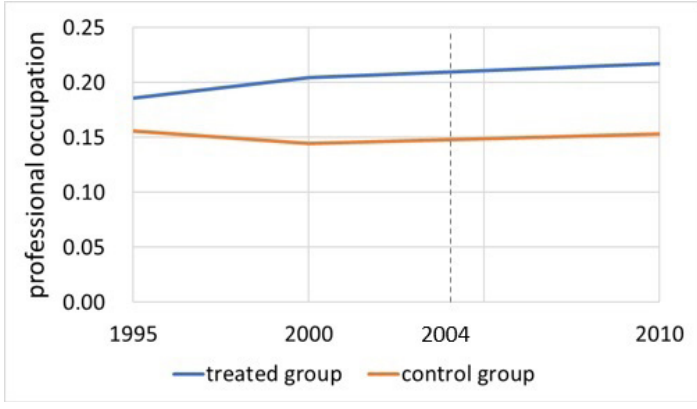

b) Professional occupation

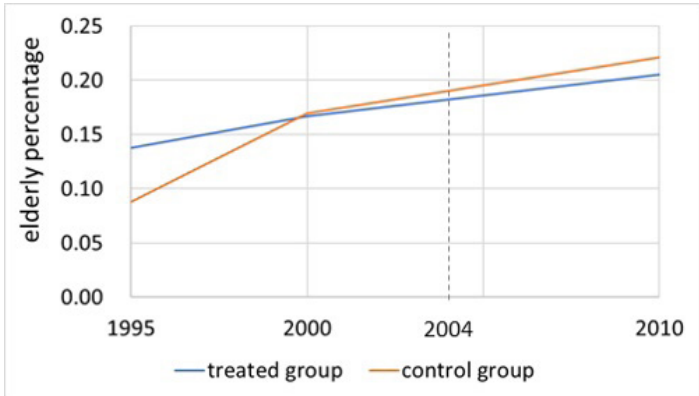

c) Older percentage

Figure 6. Average outcome trend in treated and control groups (Meijo line)

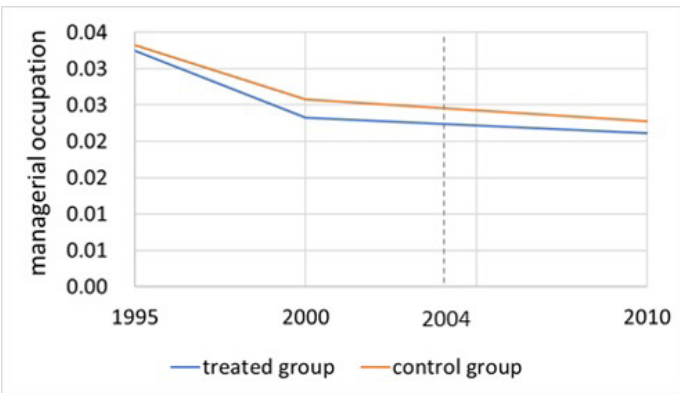

a) Managerial occupation

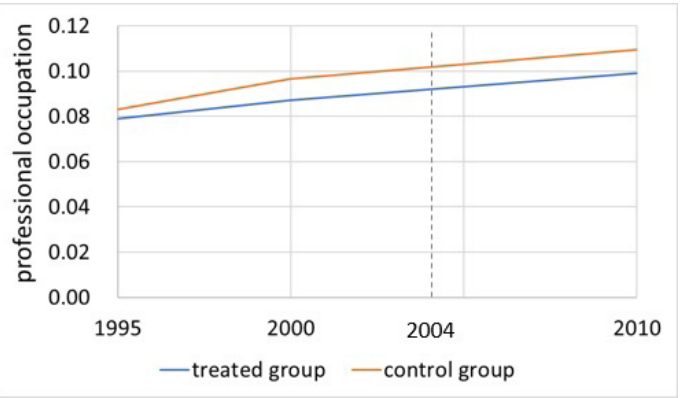

b) Professional occupation

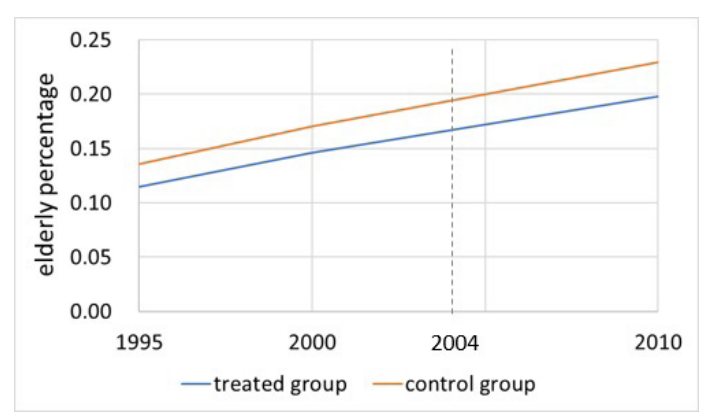

c) Older percentage

Figure 7. Average outcome trend in treated and control groups (Aonami line) 


\subsection{Standard DID panel data model estimation}

Via the splm package in $\mathrm{R}$, maximum likelihood (ML) estimator is utilized to estimate the baseline model defined using Equation 1 for each lines are listed in Tables 3 and 4. The descriptive statistics are presented in Table 5. From Table 3, we observe that the neighborhoods within $0.8 \mathrm{~km}$ of Meijo line railway station experienced $100^{*}\left(e^{0.016}-1\right)=1.6 \%$ significant increase in household income, $0.8 \%$ significant decrease in educational attainment, and $1.1 \%$ significant decrease in the older percentage. Table 4 shows the treatment estimate of Aonami line. It can be seen from the table that $0.9 \%$ significant increase was observed in student percentage model and $1 \%$ significant decrease was observed in educational attainment model.

Table 3. Standard DID panel data model estimation (Meijo line)

\begin{tabular}{|c|c|c|c|c|c|c|}
\hline Variables & $\begin{array}{l}\text { ln (Household } \\
\text { income) }\end{array}$ & $\begin{array}{l}\text { Educational } \\
\text { attainment }\end{array}$ & $\begin{array}{l}\text { Managerial } \\
\text { occupation }\end{array}$ & $\begin{array}{l}\text { Professional } \\
\text { occupation }\end{array}$ & $\begin{array}{l}\text { Older } \\
\text { percentage }\end{array}$ & $\begin{array}{l}\text { Student } \\
\text { percentage }\end{array}$ \\
\hline Intercept & $6.358(0.033)^{* * *}$ & $0.229(0.027)^{* * *}$ & $0.041(0.012)^{* * *}$ & $0.224(0.022)^{* * *}$ & $0.289(0.010)^{* * *}$ & $0.114(0.008)^{* * *}$ \\
\hline$G$ & $0.021(0.007)^{* *}$ & $0.063(0.007)^{* * *}$ & $0.012(0.002)^{* * *}$ & $0.038(0.004)^{* * *}$ & $0.006(0.006)$ & $0.026(0.004)^{* * *}$ \\
\hline$T$ & $-0.060(0.003)^{* * *}$ & $0.049(0.002)^{* * *}$ & $-0.007(0.001)^{* * *}$ & $0.015(0.002)^{* * *}$ & $0.043(0.002)^{* * *}$ & $-0.011(0.002)^{* * *}$ \\
\hline$G \circ T$ & $0.016(0.005)^{* * *}$ & $-0.008(0.004)^{*}$ & $-0.002(0.002)$ & $0.002(0.004)$ & $-0.011(0.005)^{*}$ & $0.001(0.004)$ \\
\hline $\begin{array}{l}\text { Distance to } \\
\text { CBD }\end{array}$ & $0.000(0.001)$ & $-0.004(0.001)^{* * *}$ & $-0.003(0.000)^{* * *}$ & $-0.004(0.001)^{* * *}$ & $-0.009(0.001)^{* * *}$ & $0.003(0.001)^{* * *}$ \\
\hline $\begin{array}{l}\text { Population } \\
\text { density }\end{array}$ & $0.000(0.000)^{* * *}$ & $0.000(0.000)^{* * *}$ & $0.000(0.000)^{* * *}$ & $0.000(0.000)^{* * *}$ & $0.000(0.000)^{* * *}$ & $0.000(0.000)^{* * *}$ \\
\hline $\begin{array}{l}\text { Percent } \\
\text { foreigner }\end{array}$ & $-0.270(0.061)^{* * *}$ & $-0.168(0.051)^{* *}$ & $-0.076(0.021)^{* * *}$ & $0.176(0.039)^{* * *}$ & $-0.155(0.049)^{* *}$ & $0.211(0.037)^{* * *}$ \\
\hline Average age & $-0.005(0.000)^{* * *}$ & $-0.005(0.000)^{* * *}$ & $0.001(0.000)^{* * *}$ & $-0.002(0.000)^{* * *}$ & & \\
\hline $\begin{array}{l}\text { Percent } \\
\text { owner }\end{array}$ & $0.392(0.012)^{* * *}$ & $0.103(0.010)^{* * *}$ & $0.020(0.004)^{* * *}$ & $0.071(0.008)^{* * *}$ & $0.044(0.009)^{* * *}$ & $0.028(0.007)^{* * *}$ \\
\hline $\begin{array}{l}\text { Percent labor } \\
\text { force }\end{array}$ & $0.018(0.032)$ & $0.128(0.025)^{* * *}$ & $-0.056(0.011)^{* * *}$ & $-0.107(0.021)^{* * *}$ & & \\
\hline $\begin{array}{l}\text { Migration } \\
\text { rate }\end{array}$ & $-0.028(0.016)$ & $0.190(0.013)^{* * *}$ & $0.031(0.006)^{* * *}$ & $0.105(0.011)^{* * *}$ & $-0.135(0.013)^{* * *}$ & $0.096(0.010)^{* * *}$ \\
\hline $\begin{array}{l}\text { Worker per- } \\
\text { cent railway }\end{array}$ & $0.154(0.018)^{* * *}$ & $0.302(0.016)^{* * *}$ & $0.021(0.006)^{* * *}$ & $0.137(0.011)^{* * *}$ & $-0.072(0.015)^{* * *}$ & \\
\hline $\begin{array}{l}\text { Student per- } \\
\text { cent railway }\end{array}$ & $-0.026(0.009)^{* *}$ & $-0.024(0.007)^{* *}$ & $0.005(0.003)$ & $-0.031(0.006)^{* * *}$ & & $-0.085(0.006)^{* * *}$ \\
\hline$\phi\left(\sigma_{u}^{2} / \sigma_{\mu}^{2}\right)$ & $3.662(0.325)^{* * *}$ & $6.165(0.521)^{* * *}$ & $2.205(0.194)^{* * *}$ & $1.912(0.183)^{* * *}$ & $1.892(0.186)^{* * *}$ & $1.001(0.114)^{* * *}$ \\
\hline$R^{2}$ & 0.464 & 0.399 & 0.173 & 0.362 & 0.331 & 0.273 \\
\hline $\mathrm{N}$ & 883 & 883 & 883 & 883 & 883 & 883 \\
\hline
\end{tabular}

*** $\mathrm{P}<0.001{ }^{* *} \mathrm{P}<0.01 * \mathrm{P}<0.05 \cdot \mathrm{P}<0.1$

Standard errors are in parentheses. 
Table 4. Standard DID panel data model estimation (Aonami line)

\begin{tabular}{|c|c|c|c|c|c|c|}
\hline Variables & $\begin{array}{l}\text { ln (Household } \\
\text { income) }\end{array}$ & $\begin{array}{l}\text { Educational } \\
\text { attainment }\end{array}$ & $\begin{array}{l}\text { Managerial } \\
\text { occupation }\end{array}$ & $\begin{array}{l}\text { Professional } \\
\text { occupation }\end{array}$ & $\begin{array}{l}\text { Older } \\
\text { percentage }\end{array}$ & $\begin{array}{l}\text { Student } \\
\text { percentage }\end{array}$ \\
\hline Intercept & $6.055(0.043)^{* * *}$ & $0.071(0.025)^{* *}$ & $-0.012(0.013)$ & $0.084(0.024)^{* * *}$ & $0.235(0.020)^{* * *}$ & $0.122(0.009)^{* * *}$ \\
\hline$G$ & $0.000(0.007)$ & $0.002(0.004)$ & $-0.004(0.002)$ & $-0.002(0.004)$ & $-0.022(0.008)^{* *}$ & $-0.005(0.004)$ \\
\hline$T$ & $-0.067(0.004)^{* * *}$ & $0.036(0.002)^{* * *}$ & $-0.002(0.001)$ & $0.013(0.002)^{* * *}$ & $0.053(0.003)^{* * *}$ & $-0.017(0.002)^{* * *}$ \\
\hline$G \circ T$ & $-0.001(0.007)$ & $-0.010(0.004)^{* *}$ & $0.001(0.002)$ & $-0.007(0.004)$. & $-0.005(0.006)$ & $0.009(0.005)^{*}$ \\
\hline $\begin{array}{l}\text { Distance to } \\
\text { CBD }\end{array}$ & $-0.004(0.001)^{* *}$ & $-0.006(0.001)^{* * *}$ & $-0.003(0.000)^{* * *}$ & $-0.002(0.001)^{*}$ & $-0.004(0.002)^{*}$ & $0.003(0.001)^{* * *}$ \\
\hline $\begin{array}{l}\text { Population } \\
\text { density }\end{array}$ & $0.000(0.000)^{* * *}$ & $0.000(0.000)$ & $0.000(0.000)^{* *}$ & $0.000(0.000)$ & $0.000(0.000)^{* *}$ & $0.000(0.000)^{* * *}$ \\
\hline $\begin{array}{l}\text { Percent for- } \\
\text { eigner }\end{array}$ & $-0.304(0.089)^{* * *}$ & $-0.092(0.051)$ & $-0.034(0.026)$ & $-0.068(0.049)$ & $-0.186(0.089)^{*}$ & $-0.039(0.049)$ \\
\hline Average age & $-0.002(0.001)^{* * *}$ & $-0.003(0.000)^{* * *}$ & $0.001(0.000)^{* * *}$ & $-0.001(0.000)^{* *}$ & & \\
\hline Percent owner & $0.465(0.013)^{* * *}$ & $0.048(0.008)^{* * *}$ & $0.000(0.004)$ & $0.022(0.007)^{* *}$ & $0.030(0.015)^{*}$ & $0.028(0.007)^{* * *}$ \\
\hline $\begin{array}{l}\text { Percent labor } \\
\text { force }\end{array}$ & $0.261(0.044)^{* * *}$ & $0.199(0.025)^{* * *}$ & $0.032(0.013)^{*}$ & $0.003(0.024)$ & & \\
\hline Migration rate & $0.077(0.021)^{* * *}$ & $0.070(0.011)^{* * *}$ & $0.020(0.007)^{* *}$ & $0.048(0.011)^{* * *}$ & $-0.109(0.019)^{* * *}$ & $-0.007(0.011)$ \\
\hline $\begin{array}{l}\text { Worker per- } \\
\text { cent railway }\end{array}$ & $-0.057(0.028)^{*}$ & $0.311(0.017)^{* * *}$ & $-0.027(0.008)^{* * *}$ & $0.176(0.015)^{* * *}$ & $-0.015(0.032)$ & \\
\hline $\begin{array}{l}\text { Student per- } \\
\text { cent railway }\end{array}$ & $-0.019(0.013)$ & $-0.002(0.007)$ & $0.024(0.004)^{* * *}$ & $-0.013(0.007)$ & & $-0.041(0.008)^{* * *}$ \\
\hline$\phi\left(\sigma_{u}^{2} / \sigma_{\mu}^{2}\right)$ & $1.219(0.193)^{* * *}$ & $1.930(0.267)^{* * *}$ & $0.246(0.086)^{* *}$ & $1.088(0.176)^{* * *}$ & $2.575(0.378)^{* * *}$ & $0.296(0.090)^{* *}$ \\
\hline$R^{2}$ & 0.731 & 0.667 & 0.211 & 0.357 & 0.230 & 0.159 \\
\hline $\mathrm{N}$ & 350 & 350 & 350 & 350 & 350 & 350 \\
\hline
\end{tabular}

${ }^{* * *} \mathrm{P}<0.001{ }^{* *} \mathrm{P}<0.01{ }^{*} \mathrm{P}<0.05 \quad \mathrm{P}<0.1$

Standard errors are in parentheses.

Table 5. Descriptive statistics

\begin{tabular}{|l|l|l|l|l|l|l|l|l|}
\hline \multirow{2}{*}{ variable } & \multicolumn{4}{|c|}{ Meijo line } & \multicolumn{4}{c|}{ Aonami line } \\
\cline { 2 - 8 } & Mean & St. Dev. & Min & Max & Mean & St. Dev. & Min & Max \\
\hline Population & 1633 & 1614 & 14 & 12511 & 1373 & 1424 & 18 & 10160 \\
Population density & 9733 & 4403 & 63 & 53050 & 7809 & 4151 & 40 & 29863 \\
Average age & 42 & 4 & 27 & 61 & 42 & 5 & 27 & 62 \\
Percent foreigner & 0.02 & 0.03 & 0.00 & 0.76 & 0.02 & 0.03 & 0.00 & 0.38 \\
Percent owner-occupied & 0.48 & 0.17 & 0.00 & 1.00 & 0.50 & 0.20 & 0.00 & 1.00 \\
Percent labor force & 0.53 & 0.05 & 0.14 & 0.85 & 0.54 & 0.05 & 0.32 & 0.85 \\
Migration rate & 0.30 & 0.11 & 0.03 & 1.00 & 0.25 & 0.11 & 0.00 & 0.92 \\
Worker percent railway & 0.32 & 0.12 & 0.00 & 0.72 & 0.22 & 0.10 & 0.00 & 0.64 \\
Student percent railway & 0.43 & 0.16 & 0.00 & 1.00 & 0.52 & 0.15 & 0.00 & 1.00 \\
Household income (10,000 Yen) & 550.79 & 60.64 & 326.55 & 739.04 & 523.00 & 60.52 & 297.40 & 672.19 \\
Educational attainment & 0.25 & 0.10 & 0.03 & 0.86 & 0.14 & 0.06 & 0.00 & 0.47 \\
Managerial occupation & 0.04 & 0.03 & 0.00 & 0.25 & 0.02 & 0.02 & 0.00 & 0.25 \\
Professional occupation & 0.16 & 0.06 & 0.00 & 0.69 & 0.10 & 0.04 & 0.00 & 0.26 \\
Older percentage & 0.19 & 0.07 & 0.00 & 0.54 & 0.19 & 0.08 & 0.01 & 0.55 \\
Student percentage & 0.15 & 0.05 & 0.04 & 0.86 & 0.13 & 0.03 & 0.04 & 0.38 \\
\hline
\end{tabular}




\subsection{Spatial autocorrelation and random effects diagnostic test}

We use cut-off distance to define the spatial weight matrix (W). The spatial weight $\mathrm{w}_{-} \mathrm{ij}$ is:

$w_{i j}=\left\{\begin{array}{cc}1 & 0<d_{i j} \leq d \\ 0 & \text { others }\end{array}\right.$

where $d_{i j}(i \neq j)$ is the distance between individual $i$ and individual $j$, and $d$ is the cut-off distance. In this study, for Meijo line, $d$ equals $0.8 \mathrm{~km}$ while it is $1 \mathrm{~km}$ in Aonami line. In particular, the diagonal of the spatial weight matrix is zero, that is, $w_{i i}=0$. Then, we tested the presence of spatial autocorrelation in panel data via Moran's I statistics. The statistic values in both years in each line are positive and significant. This reveals the necessity to consider spatial autocorrelation in panel data.

However, both the random effects and spatial error are in the disturbance term; hence, we tested their robustness via conditional LM test. The conditional LM test is used to analyze the joint significance for both random effects and spatial error component in the model (Baltagi et al., 2003). $\mathrm{LM}_{\lambda}$ is the conditional LM test for spatial-error autocorrelation allowing for the presence of random effects and $\mathrm{LM}_{\mu}$ is the conditional LM test for random effects allowing for the presence of spatial-error autocorrelation. Finally, the test results are presented in Table 6. The conditional LM test results in Table 6 indicate the presence of both random effect and spatial error components in panel data for all models in Meijo line; in Aonami line, the random effect is well specified in all models, and the spatial error component should not be ignored except in educational attainment and managerial occupation models.

Table 6. Lagrange multiplier test results

\begin{tabular}{|l|c|c|c|c|}
\hline \multirow{2}{*}{} & \multicolumn{2}{|c|}{ Meijo line } & \multicolumn{2}{c|}{ Aonami line } \\
\cline { 2 - 5 } & $\mathbf{L M}_{\lambda}$ & $\mathbf{L M}_{\mu}$ & $\mathbf{L M}_{\lambda}$ & $\mathbf{L M}_{\mu}$ \\
\hline $\ln$ (Household income) & $20.58^{* * *}$ & $19.35^{* * *}$ & $11.24^{* * *}$ & $11.25^{* * *}$ \\
\hline Educational attainment & $4.61^{* * *}$ & $19.62^{* * *}$ & 1.12 & $11.16^{* * *}$ \\
\hline Managerial occupation & $2.94^{* *}$ & $14.21^{* * *}$ & 0.19 & $3.22^{* *}$ \\
\hline Professional occupation & $4.33^{* * *}$ & $14.85^{* * *}$ & $2.02^{*}$ & $8.99^{* * *}$ \\
\hline Older percentage & $12.09^{* * *}$ & $16.67^{* * *}$ & $5.88^{* * *}$ & $11.72^{* * *}$ \\
\hline Student percentage & $7.02^{* * *}$ & $8.05^{* * *}$ & $4.80^{* * *}$ & $3.55^{* * *}$ \\
\hline
\end{tabular}

*** $\mathrm{P}<0.001{ }^{* *} \mathrm{P}<0.01 * \mathrm{P}<0.05 \cdot \mathrm{P}<0.1$

\subsection{Spatial DID panel data with spatial autocorrelation}

\subsubsection{Meijo line}

For Meijo line, the diagnostic test results prove the presence of spatial error autocorrelation and random effect. In this study, these nearby neighborhoods within $0.8 \mathrm{~km}$ of a directly treated neighborhood for Meijo line are defined as indirectly treated neighborhoods. Via splm package in R, the estimation results of six spatial DID panel data models (spatial DID models with one-way random effect) with spatial error components are shown in Table 7. 
Table 7. ML estimation results of spatial DID panel data models with spatial error (Meijo line)

\begin{tabular}{|c|c|c|c|c|c|c|}
\hline Variables & $\begin{array}{l}\text { In (Household } \\
\text { income) }\end{array}$ & $\begin{array}{l}\text { Educational } \\
\text { attainment }\end{array}$ & $\begin{array}{l}\text { Managerial } \\
\text { occupation }\end{array}$ & $\begin{array}{l}\text { Professional } \\
\text { occupation }\end{array}$ & $\begin{array}{l}\text { Older } \\
\text { percentage }\end{array}$ & $\begin{array}{l}\text { Student } \\
\text { percentage }\end{array}$ \\
\hline Intercept & $6.258(0.033)^{* * *}$ & $0.236(0.031)^{* * *}$ & $0.030(0.013)^{*}$ & $0.196(0.023)^{* * *}$ & $0.297(0.012)^{* * *}$ & $0.109(0.009)^{* * *}$ \\
\hline$G$ & $-0.006(0.009)$ & $0.001(0.008)$ & $0.007(0.003)^{*}$ & $0.018(0.006)^{* *}$ & $0.001(0.007)$ & $0.014(0.006)^{*}$ \\
\hline$T$ & $-0.065(0.006)^{* * *}$ & $0.043(0.006)^{* * *}$ & $-0.007(0.002)^{* * *}$ & $0.014(0.003)^{* * *}$ & $0.045(0.003)^{* * *}$ & $-0.015(0.004)^{* * *}$ \\
\hline$G \circ T$ & $0.007(0.007)$ & $0.008(0.006)$ & $-0.001(0.003)$ & $0.001(0.006)$ & $0.000(0.006)$ & $-0.002(0.006)$ \\
\hline$W G \circ T$ & $0.011(0.009)$ & $-0.009(0.007)$ & $0.000(0.004)$ & $0.004(0.007)$ & $-0.015(0.008)$ & $0.005(0.007)$ \\
\hline $\begin{array}{l}\text { Distance to } \\
\text { CBD }\end{array}$ & $0.001(0.003)$ & $-0.007(0.003)^{*}$ & $-0.003(0.001)^{* * *}$ & $-0.004(0.001)^{* * *}$ & $-0.009(0.001)^{* * *}$ & $0.004(0.001)^{* * * *}$ \\
\hline $\begin{array}{l}\text { Population } \\
\text { density }\end{array}$ & $0.000(0.000)^{* * *}$ & $0.000(0.000)^{* * *}$ & $0.000(0.000)^{* * *}$ & $0.000(0.000)^{* * *}$ & $0.000(0.000)^{* * *}$ & $0.000(0.000)^{* * *}$ \\
\hline $\begin{array}{l}\text { Percent for- } \\
\text { eigner }\end{array}$ & $-0.189(0.047)^{* * *}$ & $-0.162(0.041)^{* * *}$ & $-0.068(0.019)^{* * *}$ & $0.204(0.035)^{* * *}$ & $-0.125(0.047)^{* *}$ & $0.209(0.033)^{* * *}$ \\
\hline Average age & $-0.004(0.000)^{* * *}$ & $-0.005(0.000)^{* * *}$ & $0.001(0.000)^{* * *}$ & $-0.002(0.000)^{* * *}$ & & \\
\hline Percent owner & $0.400(0.009)^{* * *}$ & $0.110(0.008)^{* * *}$ & $0.022(0.004)^{* * *}$ & $0.061(0.007)^{* * *}$ & $0.043(0.009)^{* * *}$ & $0.028(0.006)^{* * *}$ \\
\hline $\begin{array}{l}\text { Percent labor } \\
\text { force }\end{array}$ & $0.059(0.026)^{*}$ & $0.162(0.022)^{* * *}$ & $-0.036(0.011)^{* *}$ & $-0.055(0.020)^{* *}$ & & \\
\hline Migration rate & $-0.011(0.014)$ & $0.143(0.011)^{* * *}$ & $0.023(0.006)^{* * *}$ & $0.087(0.011)^{* * *}$ & $-0.124(0.013)^{* * *}$ & $0.064(0.010)^{* * *}$ \\
\hline $\begin{array}{l}\text { Worker per- } \\
\text { cent railway }\end{array}$ & $0.107(0.019)^{* * *}$ & $0.190(0.017)^{* * *}$ & $0.004(0.007)$ & $0.096(0.014)^{* * *}$ & $-0.089(0.017)^{* * *}$ & \\
\hline $\begin{array}{l}\text { Student per- } \\
\text { cent railway }\end{array}$ & 0.003(0.008) & $0.020(0.007)^{* *}$ & $0.013(0.003)^{* * *}$ & $-0.005(0.006)$ & & $-0.052(0.007)^{* * *}$ \\
\hline$\phi\left(\sigma_{u}^{2} / \sigma_{\varepsilon}^{2}\right)$ & $2.223(0.208)^{* * *}$ & $2.814(0.239)^{* * *}$ & $1.506(0.146)^{* * *}$ & $1.255(0.128)^{* * *}$ & $2.052(0.198)^{* * *}$ & $0.621(0.083)^{* * *}$ \\
\hline$\rho$ & $0.750(0.021)^{* * *}$ & $0.800(0.019)^{* * *}$ & $0.545(0.035)^{* * *}$ & $0.617(0.032)^{* * *}$ & $0.43(0.036)^{* * *}$ & $0.598(0.033)^{* * *}$ \\
\hline$R^{2}$ & 0.468 & 0.192 & 0.138 & 0.188 & 0.343 & 0.154 \\
\hline $\mathrm{N}$ & 883 & 883 & 883 & 883 & 883 & 883 \\
\hline
\end{tabular}

*** $\mathrm{P}<0.001{ }^{* *} \mathrm{P}<0.01{ }^{*} \mathrm{P}<0.05 \cdot \mathrm{P}<0.1 \quad$ Standard errors are in parentheses.

In Table 7, $\phi$ is the ratio of the variance of the unobserved individual-specific effect $\left(\sigma_{u}^{2}\right)$ and the variance of the spatially uncorrelated disturbances $\left(\sigma_{\varepsilon}^{2}\right)$. The parameters on spatial autocorrelation error parameter $(\rho)$ are statistically significant, showing a high level of spatial autocorrelation in all models. The average direct, indirect, and total treatment effect estimates for these measures are presented in Table 8 for further analysis. Bardaka et al. (2018) defined $(\bar{w} g=E[W D \mid d=1])$ as the average proportion of directly treated neighborhoods for the treated groups to represent the treated groups and their surrounding areas. This measurement value of $\overline{w g}$ is equal to 0.721 for Meijo line. Based on Equation 6, the ATE and its variance can be computed. Take the household income model for instance, the average total treatment effect is:

$$
\begin{aligned}
& \operatorname{ATE}(\overline{w g})=\alpha_{4} \\
& +\alpha_{4, \lambda} \overline{w g}=0.007+(0.011 \times 0.721)=0.015 \\
& \begin{aligned}
\operatorname{Var}[\operatorname{ATE}(\bar{w} g)] & \left.=\operatorname{Var}\left(\alpha_{4}\right)+\left[\overline{w g}^{2} \operatorname{Var}\left(\alpha_{4, \lambda}\right)\right)\right]+\left[2 \overline{w g} \operatorname{Cov}\left(\alpha_{4}, \alpha_{4, \lambda}\right)\right] \\
& =0.007^{2}+\left[0.721^{2} \times 0.009^{2}\right]+\left[2 \times 0.721 \times\left(-9.722492 \mathrm{e}^{-6}\right)\right] \\
& =78.460 \mathrm{e}^{\wedge-6}
\end{aligned}
\end{aligned}
$$


The standard variance of $\operatorname{ATE}(\overline{w g}): \operatorname{St} . \mathrm{d}(\operatorname{ATE}(\overline{w g}))=0.009$

For direct treatment effect, in the case of a semi-logarithmic equation, the marginal effect of the independent variable is:

$\% \frac{d y}{y}=100 \times\left(\mathrm{e}^{\alpha 4}-1\right)$

For indirect treatment effect, in the case of a semi-logarithmic equation, the marginal effect of the independent variable is:

$\% \frac{d y}{y}=100 \times \alpha_{4, \lambda} \times d(w d)$

where $d(w d)$ is the change in independent variable. In household income, for a $10 \%$ increase in the proportion of directly treated neighborhoods, the opening of Meijo line caused a $100 \times\left(\mathrm{e}^{\alpha 4}-1\right)+100 \times \alpha_{4, \lambda} \times 0.1$ $=100 \times\left(e^{0.007}-1\right)+100 \times 0.011 \times 0.1=0.81$ percent increase between 2000 and 2010 . The other independent variables in Table 8 is measured in percentage points. For instance, in the case of educational attainment, for the 0.1 increase in the proportion of directly treated neighborhoods, there was $100 \times \alpha_{4}+100 \times 0.1 \times$ $\alpha_{4, \lambda}=0.8+10 \times(-0.009)=0.71$ percent increase.

Regarding average directly treated effect, we find that the neighborhoods located within $0.8 \mathrm{~km}$ of the Meijo line station experienced an increase in household income, educational attainment and professional occupation, but a decrease in managerial occupation and student percentage. With respect to indirectly treated effect, there are some positive local spillover effects to the treatment for household income, professional occupation, and student percentage, and some negative local spillover effects to the treatment for educational attainment and older percentage. Lastly, for a neighborhood within $0.8 \mathrm{~km}$ of Meijo line stations and for $10 \%$ increase in the proportion of directly treated neighborhoods, there was $0.81 \%$ average increase in average household income between 2000-2010 year, owing to the development of Meijo line.

Table 8. Average direct, indirect, and total treatment effects (Meijo line)

\begin{tabular}{|l|l|l|l|l|l|l|}
\hline & $\begin{array}{l}\ln (\text { Household } \\
\text { income })\end{array}$ & $\begin{array}{l}\text { Educational } \\
\text { attainment }\end{array}$ & $\begin{array}{l}\text { Managerial } \\
\text { occupation }\end{array}$ & $\begin{array}{l}\text { Professional } \\
\text { occupation }\end{array}$ & $\begin{array}{l}\text { Older percent- } \\
\text { age }\end{array}$ & $\begin{array}{l}\text { Student per- } \\
\text { centage }\end{array}$ \\
\hline ADTE & $0.007(0.007)$ & $0.008(0.006)$ & $-0.001(0.003)$ & $0.001(0.006)$ & $0.000(0.006)$ & $-0.002(0.006)$ \\
AITE & $0.011(0.009)$ & $-0.009(0.007)$ & $0.000(0.004)$ & $0.004(0.007)$ & $-0.015(0.008) \cdot$ & $0.005(0.007)$ \\
ATE & $0.015(0.009) \cdot$ & $0.001(0.007)$ & $-0.001(0.003)$ & $0.003(0.007)$ & $-0.011(0.007)$ & $0.001(0.007)$ \\
\hline
\end{tabular}

*** $\mathrm{P}<0.001{ }^{* *} \mathrm{P}<0.01 * \mathrm{P}<0.05 \cdot \mathrm{P}<0.1 \quad$ Standard errors are in parentheses.

\subsubsection{Aonami line}

For Aonami line, the diagnostic test results indicate that random effect exist in all models, there is spatial error autocorrelation in all models except for educational attainment and managerial occupation models. The estimation results of spatial DID panel data model with or without spatial error components are presented in Table 9. From this table a significant positive directly treated effect in student percentage model can be observed. Except for managerial occupation and student percentage, there are negative directly treated effects in other models. This indicates that the investment on Aonami line didn't have 
significant direct treatment effects on gentry that have high-income, is highly educated and have professional occupation, or older population. However, the student population show a significant positive trend. There is no significant indirectly treated effect in all models, but indirectly treated effects are positive in household income model, older percentage model and student percentage model.

Table 9. ML estimation results of spatial DID panel data models with and without spatial error (Aonami line)

\begin{tabular}{|c|c|c|c|c|c|c|}
\hline Variables & $\begin{array}{l}\text { In (Household } \\
\text { income) }\end{array}$ & $\begin{array}{l}\text { Educational } \\
\text { attainment }\end{array}$ & $\begin{array}{l}\text { Managerial } \\
\text { occupation }\end{array}$ & $\begin{array}{l}\text { Professional } \\
\text { occupation }\end{array}$ & $\begin{array}{l}\text { Older } \\
\text { percentage }\end{array}$ & \begin{tabular}{|l|}
$\begin{array}{l}\text { Student } \\
\text { percentage }\end{array}$ \\
\end{tabular} \\
\hline Intercept & $6.048(0.045)^{* * *}$ & $0.071(0.025)^{* *}$ & $-0.011(0.013)$ & $0.085(0.024)^{* * *}$ & $0.235(0.020)^{* * *}$ & $0.122(0.009)^{* * *}$ \\
\hline$G$ & $-0.002(0.010)$ & $0.002(0.004)$ & $-0.004(0.002)$ & $-0.002(0.004)$ & $-0.023(0.008)^{* *}$ & $-0.005(0.004)$ \\
\hline$T$ & $-0.068(0.006)^{* * *}$ & $0.036(0.002)^{* * *}$ & $-0.002(0.001)$ & $0.014(0.002)^{* * *}$ & $0.053(0.003)^{* * *}$ & $-0.017(0.002)^{* * *}$ \\
\hline$G \circ T$ & $-0.007(0.012)$ & $-0.009(0.007)$ & $0.005(0.004)$ & $-0.003(0.007)$ & $-0.005(0.006)$ & $0.009(0.005)^{*}$ \\
\hline$W G \circ T$ & $0.007(0.017)$ & $-0.001(0.009)$ & $-0.005(0.005)$ & $-0.005(0.009)$ & $0.000(0.008)$ & $0.000(0.005)$ \\
\hline $\begin{array}{l}\text { Distance to } \\
\text { CBD }\end{array}$ & $-0.003(0.002)$ & $-0.006(0.001)^{* * *}$ & $-0.003(0.000)^{* * *}$ & $-0.002(0.001)^{*}$ & $-0.004(0.002)^{*}$ & $0.003(0.001)^{* * *}$ \\
\hline $\begin{array}{l}\text { Population } \\
\text { density }\end{array}$ & $0.000(0.000)^{* * *}$ & $0.000(0.000)$ & $0.000(0.000)^{* *}$ & $0.000(0.000)$ & $0.000(0.000)^{* *}$ & $0.000(0.000)^{* * *}$ \\
\hline $\begin{array}{l}\text { Percent for- } \\
\text { eigner }\end{array}$ & $-0.275(0.085)^{* *}$ & $-0.092(0.051)$ & $-0.034(0.026)$ & $-0.067(0.049)$ & $-0.186(0.089)^{*}$ & $-0.039(0.049)$ \\
\hline Average age & $-0.002(0.001)^{* * *}$ & $-0.003(0.000)^{* * *}$ & $0.001(0.000)^{* * *}$ & $-0.001(0.000)^{* *}$ & & \\
\hline Percent owner & $0.454(0.013)^{* * *}$ & $0.048(0.008)^{* * *}$ & $0.000(0.004)$ & $0.022(0.007)^{* *}$ & $0.030(0.015)^{*}$ & $0.028(0.007)^{* * *}$ \\
\hline $\begin{array}{l}\text { Percent labor } \\
\text { force }\end{array}$ & $0.268(0.041)^{* * *}$ & $0.199(0.025)^{* * *}$ & $0.032(0.013)^{*}$ & $0.002(0.024)$ & & \\
\hline Migration rate & $0.073(0.019)^{* * *}$ & $0.070(0.011)^{* * *}$ & $0.019(0.007)^{* *}$ & $0.048(0.011)^{* * *}$ & $-0.109(0.019)^{* * *}$ & $-0.007(0.011)$ \\
\hline $\begin{array}{l}\text { Worker per- } \\
\text { cent railway }\end{array}$ & $-0.038(0.032)$ & $0.311(0.017)^{* * *}$ & $-0.028(0.008)^{* * *}$ & $0.175(0.015)^{* * *}$ & $-0.014(0.032)$ & \\
\hline $\begin{array}{l}\text { Student per- } \\
\text { cent railway }\end{array}$ & $-0.015(0.012)$ & $-0.002(0.007)$ & $0.024(0.004)^{* * *}$ & $-0.013(0.007)$ & & $-0.041(0.008)^{* * *}$ \\
\hline$\phi\left(\sigma_{u}^{2} / \sigma_{\varepsilon}^{2}\right)$ & $1.645(0.246)^{* * *}$ & $1.928(0.268)^{* * *}$ & $0.241(0.086)^{* *}$ & $1.080(0.176)^{* * *}$ & $2.576(0.379)^{* * *}$ & $0.296(0.091)^{* *}$ \\
\hline$\rho$ & $0.477(0.060)^{* * *}$ & & & & & \\
\hline$R^{2}$ & 0.706 & 0.667 & 0.212 & 0.357 & 0.230 & 0.159 \\
\hline $\mathrm{N}$ & 350 & 350 & 350 & 350 & 350 & 350 \\
\hline
\end{tabular}

*** $\mathrm{P}<0.001{ }^{* *} \mathrm{P}<0.01{ }^{*} \mathrm{P}<0.05 \cdot \mathrm{P}<0.1 \quad$ Standard errors are in parentheses.

In Aonami line, the value of $\overline{w g}$ is 0.769 , and the average direct, indirect, and total treatment effect estimates are presented in Table 10. The calculated average treatment effect in educational attainment model is significant negative in Table 10. For a neighborhood within $1 \mathrm{~km}$ from Aonami line stations and for $10 \%$ increase in the proportion of directly treated neighborhoods, there was 0.91 percent decrease in educational attainment. To conclude, the average treatment effects of Aonami line are negative for the gentry with high household income, high education and professional occupation, and the older. Students, on the contrary, show significant interests. 
Table 10. Average direct, indirect, and total treatment effects (Aonami line)

\begin{tabular}{|lllllll|}
\hline & $\begin{array}{l}\text { In (Household } \\
\text { income) }\end{array}$ & $\begin{array}{l}\text { Educational } \\
\text { attainment }\end{array}$ & $\begin{array}{l}\text { Managerial } \\
\text { occupation }\end{array}$ & $\begin{array}{l}\text { Professional } \\
\text { occupation }\end{array}$ & $\begin{array}{l}\text { Older } \\
\text { percentage }\end{array}$ & $\begin{array}{l}\text { Student } \\
\text { percentage }\end{array}$ \\
\hline ADTE & $-0.007(0.012)$ & $-0.009(0.007)$ & $0.005(0.004)$ & $-0.003(0.007)$ & $-0.005(0.006)$ & $0.009(0.005)^{*}$ \\
AITE & $0.007(0.017)$ & $-0.001(0.009)$ & $-0.005(0.005)$ & $-0.005(0.009)$ & $0.000(0.008)$ & $0.000(0.005)$ \\
ATE & $-0.001(0.010)$ & $-0.010(0.004)^{* *}$ & $0.001(0.003)$ & $-0.007(0.004) \cdot$ & $-0.005(0.009)$ & $0.009(0.006)$ \\
\hline
\end{tabular}

*** $\mathrm{P}<0.001{ }^{* *} \mathrm{P}<0.01{ }^{*} \mathrm{P}<0.05 \cdot \mathrm{P}<0.1 \quad$ Standard errors are in parentheses.

\section{$5 \quad$ Discussion and conclusions}

This research focuses on the effects of two different railway investments on neighborhood change and local spillover effect in Nagoya, Japan. Different from previous studies, this paper investigates railwayinduced effects on different social classes not only the gentry. Meanwhile, as the multimode bicyclerailway daily trips are common in Nagoya, it is necessary to observe the indirectly treated effects, or local spillover effects in models. Further, we tested the robustness of random effect and spatial error component in models through LM test. However, if we consider spatial autocorrelation in DID model directly, it will break the SUTVA assumption and make the estimation results biased and inconsistent. Inspired by Delgado and Florax (2015), the spatial DID panel data model is implemented to estimate parameters for each line. Under the background of sluggish economy, the relocation preferences may be influenced. Therefore, although the estimation results show less significances, it is still acceptable.

After comparing the estimation results in two lines, we found that there were some differences between two lines. First, we observed that the average treatment effects in Table 8 are positive in household income model, educational attainment model, and professional occupation model for Meijo line. However, it was opposite for Aonami line. This reveals that the gentry (which are population above 25 years old with at least a bachelor's degree and professional background with high income) are attracted to live along the Meijo line; however, the investment of Aonami line could not attract them because of different land use and urbanization level along the two lines. From Nagoya city planning, it was found that $79 \%$ of the areas within $0.8 \mathrm{~km}$ of Meijo line station are residential land, and three business districts are located on this line; however, only $44 \%$ of the areas within $1 \mathrm{~km}$ of Aonami line station are residential land, and more than $50 \%$ of the land is occupied by industries. And there is no business district in the study area of Aonami line. Meanwhile, Aonami line is the only railway line in that suburban area, and the accessibility of railway transportation is limited. Therefore, the convenient commercial and good living conditions along Meijo line is more appealing to the gentry.

To conclude, the railway investments in highly urbanized area is more likely to induce gentrification. Moreover, as public transport is the common mode for students, they prefer the residences near railway stations. However, the housing prices along Meijo line are higher. Since the bicycle plots along this line can improve bicycle-railway trips, students can afford living a little further away from railway stations. Hence, Meijo line induced positive indirect treated effect on students. Due to the lower housing prices along Aonami line, students can dwell closer to railway stations. We observed significant direct treated effect caused by Aonami line.

Meanwhile, there are some identical conclusions for two lines. First, unlike the students, no significant railway-induced effect was found for the older population. This result may be reasonable. One plausible explanation is that since almost all the older live on a pension in Japan, they prefer to live in the communities with lower housing cost but apart from railway stations. In addition, the bus network 
in big city in Japan provide a good service to older population, even though the service frequency of bus is lower than that of railway. Therefore, the older would not move to the area around the station. Second, for the students, the railway investments have positive effect to them. The main reasons are: a) The railway stops at many high schools and colleges, which is convenient for them to go to school. b) There were few schools in the areas around Aonami line from 2000 and 2010. Hence, if these students go to school by public transport modes, they may need to transfer. Considering the sound railway network in Nagoya city, railway transportation would be more convenient for transferring.

In terms of designing city planning policy, the following conclusions are helpful. Clearly, the railway investments in highly urbanized area is attractive to the gentry. Therefore, real estate developers can build more high-quality housing in such area. In the lower urbanized area, the residences along the railway line appeal to students. Hence, more apartments for rent can be built along this line.

With respect to transport policy, we observe that the bicycles lots along Meijo line extend students' accessibility of railway stations. It is necessary to design bicycles lots around railway stations. However, since the railway is not appealing to the older population, planners need to devise a more effective solution to reduce the high traffic accident rates of the older, such as robotaxi.

The real estate transaction-price can be an alternative representative measure. We can obtain the sales information during the period from 2000 to 2010 from the Ministry of Land, Infrastructure, Transport and Tourism, Japan. However, the number of records within the study area are not sufficient for research. Therefore, we did not use the sales price data. Furthermore, the geographical scale used is based on preliminary study. We can do more work to compare the estimation results among different scales.

\section{Acknowledgements}

This work was supported by JSPS KAKENHI Grant Number 19H02260. The authors gratefully acknowledge their support. This support does not limit any research work including paper publication and patent application. 


\section{References}

Abadie, A. (2005). Semiparametric difference-in-differences estimators. Review of Economic Studies, 72(1), 1-19. https://doi.org/10.1111/0034-6527.00321

Atkinson, R. (2000). Measuring gentrification and displacement in Greater London. Urban Studies, $37(1), 149-165$.

Baltagi, B. H., Song, S. H., \& Koh, W. (2003). Testing panel data regression models with spatial error correlation. Journal of Econometrics, 117(1), 123-150. https://doi.org/10.1016/S03044076(03)00120-9

Bardaka, E., Delgado, M. S., \& Florax, R. J. G. M. (2018). Causal identification of transit-induced gentrification and spatial spillover effects: The case of the Denver light rail. Journal of Transport Geography, 71(July), 15-31. https://doi.org/10.1016/j.jtrangeo.2018.06.025

Barsby, S. L., \& Cox, D. R. (1975). Interstate migration of the elderly: An economic analysis. Washington, DC: Lexington books.

Bluestone, B., Huff Stevenson, M., \& Williams, R. (2008). The urban experience: Economics, society, and public policy. Oxford, UK: Oxford Univeristy Press.

Cervero, R. (2010). Effects of light and commuter rail transit on land prices: Experiences in San Diego County. Journal of the Transportation Research Forum, 43(1), 120-138. https://doi.org/10.5399/osu/ jtrf.43.1.741

Chapple, K., Austin, M., Coleman, R., Martin, A., Meigs, N., Munekiyo, T., ... Wampler, E. (2009). Mapping susceptibility to gentrification: The early warning toolkit. Retrieved from http://communityinnovation.berkeley.edu/reports/Gentrification-Report.pdf

Chi, G., \& Voss, P. R. (2005). Migration decision-making: A hierarchical regression approach. Journal of Regional Analysis and Policy, 35(2), 11-22.

Delgado, M. S., \& Florax, R. J. G. M. (2015). Difference-in-differences techniques for spatial data: Local autocorrelation and spatial interaction. Economics Letters, 137, 123-126. https://doi.org/10.1016/j. econlet.2015.10.035

Dubé, J., Legros, D., Thériault, M., \& Des Rosiers, F. (2014). A spatial difference-in-differences estimator to evaluate the effect of change in public mass transit systems on house prices. Transportation Research Part B: Methodological, 64(6), 24-40. https://doi.org/10.1016/j.trb.2014.02.007

Florida, R. (2010). Who's your city? How the creative economy is making where to live the most important decision of your life. Toronto: Vintage Canada.

Grossmann, K., \& Haase, A. (2016). Neighborhood change beyond clear storylines: What can assemblage and complexity theories contribute to understandings of seemingly paradoxical neighborhood development? Urban Geography, 37(5), 727-747. https://doi.org/10.1080/02723638.2015.11138 07

Grube-Cavers, A., \& Patterson, Z. (2015). Urban rapid rail transit and gentrification in Canadian urban centres: A survival analysis approach. Urban Studies, 52(1), 178-194. https://doi. org/10.1177/0042098014524287

Hammel, D. J., \& Wyly, E. K. (1996). A model for identifying gentrified areas with census data. Urban Geography, 17(3), 248-268. https://doi.org/10.2747/0272-3638.17.3.248

Helms, A. C. (2003). Understanding gentrification: An empirical analysis of the determinants of urban housing renovation. Journal of Urban Economics, 54(3), 474-498. https://doi.org/10.1016/S00941190(03)00081-0

Kahn, M. E. (2007). Gentrification trends in new transit-oriented communities: Evidence from 14 cities that expanded and built rail transit systems. Real Estate Economics, 35(2), 155-182. https://doi. 
org/10.1111/j.1540-6229.2007.00186.x

Kapoor, M., Kelejian, H. H., \& Prucha, I. R. (2007). Panel data models with spatially correlated error components. Journal of Econometrics, 140(1), 97-130. https://doi.org/10.1016/j.jeconom.2006.09.004

Kilpatrick, J. A., Throupe, R. L., Carruthers, J. I., \& Krause, A. (2007). The impact of transit corridors on residential property values. Journal of Real Estate Research, 29(3), 303-320. https://doi.org/10.10 80/10835547.2007.12091201

Lin, J. (2002). Gentrification and transit in Northwest Chicago. Transportation Quarterly, 56, 175-191.

Newman, P., \& Kenworthy, J. (1999). Sustainability and cities: overcoming automobile dependence. Washington, DC; Island press.

Park, J., \& Kim, K. (2016). The residential location choice of the elderly in Korea: A multilevel logit model. Journal of Rural Studies, 44, 261-271. https://doi.org/10.1016/j.jrurstud.2016.02.009

Plane, D., \& Jurjevich, J. (2009). Ties that no longer bind? The patterns and repercussions of age-articulated migration. Professional Geographer, 61(1), 4-20. https://doi.org/10.1080/00330120802577558

Slater, T. (2011). Gentrification of the city. The new Blackwell companion to the city. Hoboken, NJ: Wiley Blackwell.

Wang, L., Jiang, M., Miwa, T., Bardaka, E., \& Morikawa, T. (2020). Preliminary study on transitinduced residential gentrification in Nagoya, Japan. Asian Transport Studies, 6(July), 100022. https:// doi.org/10.1016/j.eastsj.2020.100022

Zuk, M., Bierbaum, A. H., Chapple, K., Gorska, K., \& Loukaitou-Sideris, A. (2018). Gentrification, displacement, and the role of public investment. Journal of Planning Literature, 33(1), 31-44. https:// doi.org/10.1177/0885412217716439 